\title{
Аналіз смертності хворих на колоректальний рак у багатопрофільних лікарнях м. Харків
}

\author{
Харківська медична академія післядипломної освіти \\ Отримано: 22.10 .2020 \\ Прийнято до друку: 17.11 .2020 \\ DOI: 10.32471/clinicaloncology.2663-466X.39-3.27380
}

\begin{abstract}
Колоректальний рак (КРP) є злоякісною пухлиною, що може викликати смертельні ускладнення навіть без значного прогресування пухлинного процесу, проте КРР може характеризуватися швидкою генералізацією без місцевих ускладнень. Мета дослідження - визначити основні клініко-морфологічні особливості КРР за даними аутопсії. Матеріали та методи. Проведено аналіз 321 аутопсії хворих, що померли внаслідок КРР у стаціонарах м. Харків. На підставі протоколів розтину та історій хвороби було досліджено такі дані: стать, вік пацієнтів, локалізація пухлини, її гістологічна будова, характер розповсюдження, дані анамнезу, безпосередня причина смерті. Результати. Серед 6635 померлих у стаціонарах багатопрофільних лікарень КРР був причиною смерті у 4,83\% (321 випадок). Первинна пухлина локалізувалася у 37,5\% хворих у сигмовидній кишці та ректосигмоїдній зоні, у 16,5\% - у сліпій кишці, у 11,9\% - у прямій кишці. Серед померлих IV стадію захворювання відмічали лише у 43,6\% (140 із 321) випадків, серед них найбільш поширеною локалізацією метастазів були печінка, легені та очеревина - у 39,5; 21,8 та 11,2\% відповідно; у 51,4\% пацієнтів метастази виявляли в одному органі. Серед причин смерті хворих на КРР найбільш поширеними були місцеві ускладнення, генералізація пухлинного процесу та перфорація пухлини була причинами смерті у 27,1 та 18,3\% випадків відповідно. Смерть після операцій, що проводилися з приводу місцевих ускладнень, найчастіше наставала внаслідок серцевої недостатності чи тромбоемболії легеневої артерії. Серед померлих лікування вперше у стаціонарі 3 приводу раку та його ускладнень відмічали у 66,3\%. Смерть внаслідок рецидивів у 1-, 2-й роки та після 5 років з моменту видалення пухлини настала у 36,5; 67,0 та 24,5\% відповідно. Висновки. Серед померлих у стаціонарі багатопрофільних лікарень КРР був причиною смерті у 4,83\%. Локалізація КРР, що найчастіше відмічалася, сигмовидна кишка та ректосигмоїдна зона - у 37,5\% випадків. Серед причин смерті хворих на КРР найбільш поширеними були місцеві ускладнення. Генералізація пухлинного процесу була причиною смерті лише в 18,3\% хворих. У $66,3 \%$ пацієнтів смерть внаслідок КРР наставала без попереднього лікування. Смерть від рецидивів у хворих, у яких пухлину було видалено раніше, відмічалася у 19,0\% випадків, серед них у перші 2 роки - у 67,0\%.
\end{abstract}

Ключові слова: колоректальний рак; аутопсія; клініко-морфологічний аналіз.

\section{ВСТУП}

У структурі смертності внаслідок злоякісних новоутворень (3Н) колоректальний рак (КРP) займає 2-ге місце [1]. Так, в Україні у 2018 р. смертність від КРР становила 13,2\% серед ЗН у чоловіків після раку трахеї, бронху та легені та $15,3 \%$ у жінок після онкопатології грудної залози. У чоловіків та жінок віком понад 75 років у 2018 р. КРР виходять на 1-ше місце серед причин смерті від усіх $3 \mathrm{H}-18,3$ та 19,0\% відповідно [1].

КРР характеризується високим відсотком хворих, що не прожили 1 року після встановлення діагнозу. Цей показник відображає занедбаність 3Н та їх агресивність [1]. Так, згідно зі статистикою за 2018 р. у Харкові серед усіх пацієнтів 3 онкопатологією цей показник становив $33,8 \%$, тоді як серед хворих на рак ободової кишки - 45,4\%, прямої кишки $-31,3 \%$, що в цілому свідчить про відсутність активного діагностування цих ЗН під час профоглядів. Це стосується навіть раку прямої кишки, локалізації, що може бути виявлена візуально [1].

Слід зазначити, що КРР є ЗН, що може призводити до таких ускладнень, як кишкова непрохідність та перфорація пухлини навіть без значного прогресування пухлинного процесу. Представляє науковий та практичний інтерес дослідження причин смерті пацієнтів з КРР та його клініко-морфологічних особливостей на етапі виникнення смертельних ускладнень.

Мета дослідження - визначення основних клініко-морфологічних особливостей КРР за даними аутопсії.

\section{МАТЕРІАЛИ ТА МЕТОДИ}

Проведено аналіз аутопсій, що були виконані у централізованому патологоанатомічному відділенні Комунального некомерційного підприємства «Міська клінічна багатопрофільна лікарня № 17» Харківської міської ради у період з 2010 р. - перше півріччя 2020 р. Загальна кількість аутопсій -6635 .

Розглянуто результати аутопсій пацієнтів, що померли внаслідок КРР, загальна кількість випадків - 321 .

Було враховані такі дані, як стать, вік пацієнтів, локалізація пухлини, iї гістологічна будова, рівень інвазії та особливості метастазування, досліджувалися дані анамнезу, а саме: час встановлення діагнозу, лікування пухлини в минулому, лікування у стаціонарі, безпосередня причина смерті.

Зв'язок між ознаками оцінювався за непараметричним критерієм $\chi^{2}$ Пірсона і критерієм Стьюдента. Статистично значущим вважалося значення $\mathrm{p}<0,05$.

\section{РЕЗУЛЬТАТИ ДОСЛІДЖЕННЯ}

За вказаний період КРР як причина смерті було зафіксовано у 4,83\% (321/6635) випадків.

Середній вік пацієнтів становив $71,2 \pm 10,7$ року. Як видно 3 табл. 1, смерть найчастіше наставала у віковому інтервалі $70-79$ років - у $28,3 \%$ хворих, тоді як у $60-69$ років - у $26,8 \%$, та у $80-89$ років. - у $25,5 \%$. Вік наймолодшого пацієнта становив 45 років. Частки чоловіків та жінок були майже однаковими - 48,3 та 51,7\% відповідно. Середній вік чоловіків становив $70,6 \pm 11,0$, жінок $-72,1 \pm 10,3$ років ( $>>0,05)$.

Серед наймолодшої вікової групи 40-49 років прослідковується тенденція до більшої кількості чоловіків - 70\%, жінок, відповідно, - 30\% (p>0,05). Серед померлих пацієнтів найстаршої вікової групи $>80$ років переважали жінки $-54,1 \%$ та чоловіки становили 45,9\% (р>0,05) (табл. 1).

Первинна пухлина локалізувалася у різних відділах товстої кишки, проте кількість випадків виникнення онкопатології у правій половині ободової кишки була дещо меншою, $32,1 \%$, ніж у лівій (із ЗН ректосигмоїдного відділу без урахування раку прямої кишки) $-44,2 \%$ (табл. 2) 
Таблиця 1. Розподіл хворих за віком і статтю

\begin{tabular}{lccc}
\hline \multicolumn{1}{c}{ Вікова група, років } & Чоловіки & Жінки & Разом \\
\hline $40-49$ & 7 & 3 & 10 \\
$50-59$ & 23 & 24 & 47 \\
$60-69$ & 45 & 41 & 86 \\
$70-79$ & 40 & 51 & 91 \\
$80-89$ & 38 & 44 & 82 \\
$>90$ & 2 & 3 & 5 \\
Разом & $\mathbf{1 5 5}$ & $\mathbf{1 6 6}$ & $\mathbf{3 2 1}$ \\
\hline
\end{tabular}

Таблиця 2. Локалізація первинної пухлини у хворих на КРР

\begin{tabular}{lcc}
\multicolumn{1}{c}{ Локалізація пухлини } & \multicolumn{2}{c}{ Кількість хворих } \\
\cline { 2 - 3 } & $\mathbf{n}$ & $\%$ \\
\hline Ілеоцекальний кут & 2 & 0,6 \\
Апендикс & 2 & 0,6 \\
Сліпа кишка & 49 & 15,3 \\
Висхідна ободова & 23 & 7,2 \\
Печінковий кут & 31 & 9,6 \\
Поперечноободова & 25 & 7,7 \\
Селезінковий кут & 15 & 4,6 \\
Низхідна ободова & 7 & 2,1 \\
Сигмоподібна кишка & 76 & 23,7 \\
Множинна локалізація & 9 & 2,9 \\
Ректосигмоїдний відділ & 44 & 13,8 \\
Пряма кишка & 38 & 11,9 \\
Усього & 321 & 100,0 \\
\hline
\end{tabular}

ЗН з множинною локалізацією відмічали у 2,8\% (9/321) хворих. Серед них були пацієнти чоловічої статі віком 47-67 років.

За гістологічною будовою пухлини були G1 у $3,1 \%$ (10/321), G2 - 48,6\% (156/321), G3 - 26,7\% (86/321) випадків, серед КРР інші гістотипи відмічали у 21,5\% (69/321) пацієнтів, а саме: муцинозна карцинома - у 10,3\% (33/321), перстньовидноклітинний рак - у 4,0\% (13/321), карциноїд - у 3,1\% (3/321), інші нейроендокринні $3 \mathrm{H}$, дрібноклітинний рак, аденокарциноми з нейроендокринним диференціюванням у 1,8\% (6/321), плоскоклітинний рак прямої кишки - у 1,2\% (4/321), первинні лімфоми - у 0,9\% (3/321).

Серед померлих внаслідок КРР у 19,9\% (64/321) відмічали проростання пухлини у суміжні органи та тканини, а саме у: передню черевну стінку - у 15,6\% (10/64), передню черевну стінку та органи малого таза - у $3,1 \%(2 / 64)$, клітковину та м'які тканини малого таза - у 9,3\% (6/24), органи малого таза - у 37,5\% (24/64), зокрема сечовий міхур - у 15,6\% (10/64), матку чи піхву - у 9,3\% (6/64), сечовий міхур та інші органи малого таза (яєчники чи передміхурову залозу) у $12,5 \%$ (8/64), сечівники та заочеревинну клітковину - у 9,3\% (6/24), підпечінковий простір із залученням дванадцятипалої кишки чи печінки - у 14,0\% (9/64), тонку кишку - у 10,9\% $(7 / 64)$.

Метастазування у віддалені лімфатичні вузли виявляли у 14,0\% (45/321) випадків. Віддалені метастази відмічали у 43,6\% (140/321) хворих. У 51,4\% (72/140) досліджених гематогенне метастазування було лише у один орган, відповідно, у 48,6\% (68/142) виявляли метастази у два і більше органів. Найбільш часто відмічали метастазування у печінку - у $39,5 \%$ (127/321) випадків. На 2-му місці за частотою ураження були легені - в 21,8\% (70/321). Метастази у наднирники виявляли у 6,2\% (20/321), нирки - у 5,9\% (19/321), підшлункову залозу - у 4,6\% (15/321), тонку кишку - у 2,8\% (9/321), головний мозок - у 2,1\% (7/321), селезінку - у $1,8 \%$ (6/321), серце у 1,2\% (4/321), кістки - у 1,2\% (4/321) хворих. Карциноматоз очеревини спостерігався у 11,2\% (36/321) пацієнтів, 3 них відсутність метастазів у внутрішні органи відмічали у $25 \%$ (9/36) випадків.

Відсутність карциноматозу очеревини, метастазування у внутрішні органи чи віддалені лімфатичні вузли, проростання у суміжні тканини та внутрішні органи була зафіксована у $36,76 \%$ (118/321) випадків. Серед причин смерті цих пацієнтів з пухлинами, що не мали значного прогресування, були: перфорація пухлини з формуванням перитоніту або абсцесів черевної порожнини - 24,5\% (29/118), дистанційний розрив стінки обо- дової кишки внаслідок кишкової непрохідності - 11,0\% 13/118), флегмона кишкової стінки та заочеревинної клітковини - 2,5\% (3/118), у 61,0\% (72/118) випадках наставали ускладнення після операцій, що проводилися у зв'язку з кишковою непрохідністю, а саме: тромбоемболія легеневої артерії - у 8,5\% (10/118) випадків, гостра серцева недостатність - у 11,1\% (13/118), неспроможність чи некроз колостоми з флегмоною - у $21,2 \%$ (25/118), неспроможність швів кишкового анастомозу - у 5,9\% (7/118), кровотеча з брижі кишки - у 6,7\% (8/118), гострий тромбоз судин кишечнику з його некрозом - у 4,3\% (5/118), перфорація стресових виразок тонкої кишки - у 3,3\% (4/118). У $0,84 \%(1 / 118)$ хворих причиною смерті стало ускладнення поліхіміотерапії з виразково-некротичним ентеритом, токсичною дистрофією печінки.

У табл. 4 наведені ускладнення КРР, що призвели до смерті. Найчастіше вона наставала у зв'язку з місцевим прогресуванням пухлинного процесу, серед цих ускладнень у 18,3\% (59/321) випадках наставала перфорація пухлини з формуванням перитоніту або абсцесів черевної порожнини; у 7,2\% (23/321) - флегмона кишкової стінки з абсцедуванням або флегмоною заочеревинної клітковини, або перитонітом; у 6,2\% (20/321) - дистанційний розрив стінки ободової кишки внаслідок кишкової непрохідності; інвазія пухлини з арозивною кровотечею та крововиливом у черевну порожнину відмічали в 1,2\% (4/321) випадків, серед ускладнень також було зафіксовано проростання пухлини у холедох з розвитком холестазу - у $0,6 \%$ (2/321), проростання сечівника з розвитком піонефрозу - у 0,3\% (1/321), також зареєстровано 1 випадок смерті внаслідок ускладнень поліхіміотерапії.

Прогресування пухлинного процесу з численними метастазами у внутрішні органи відмічали у 27,1\% (87/321) випадків.

Також смерть наставала від ускладнень після хірургічного втручання (табл. 3). Показаннями до операції у переважній більшості випадків були місцеві ускладнення, зокрема кишкова непрохідність.

Серед хворих, що померли у стаціонарі внаслідок КРР, вперше лікувалися стаціонарно з приводу $3 \mathrm{H}$ та їх усклад-

Таблиця 3. Ускладнення внаслідок КРР, що призвели до смерті

\begin{tabular}{|c|c|c|}
\hline \multicolumn{2}{|c|}{ Ускладнення від КРР } & Кількість випадків \\
\hline \multicolumn{2}{|c|}{ Місцеве прогре- Перфорацією пухлини } & $18,3 \%(59 / 321)$ \\
\hline \multirow{4}{*}{$\begin{array}{l}\text { сування пухлин- } \\
\text { ного процесу }\end{array}$} & Флегмона кишкової стінки & $7,2 \%(23 / 321)$ \\
\hline & $\begin{array}{l}\text { Дистанційний розрив стінки } \\
\text { ободової кишки }\end{array}$ & $6,2 \%(20 / 321)$ \\
\hline & Арозивна кровотеча з пухлини & $1,2 \%(4 / 321)$ \\
\hline & Інше & $1,5 \%(3 / 321)$ \\
\hline \multirow{12}{*}{$\begin{array}{l}\text { Генералізація пу } \\
\text { Серцева недост } \\
\text { Стан після опе- } \\
\text { рації }\end{array}$} & хлинного процесу & $27,1 \%(87 / 321)$ \\
\hline & атність при поєднаній патології & $1,5 \%(5 / 321)$ \\
\hline & Гостра серцева недостатність & $9,3 \%(30 / 321)$ \\
\hline & $\begin{array}{l}\text { Тромбоемболія легеневої ар- } \\
\text { терії }\end{array}$ & $6,2 \%(20 / 321)$ \\
\hline & $\begin{array}{l}\text { Некроз чи неспроможність ко- } \\
\text { лостоми }\end{array}$ & $5,0 \%(16 / 321)$ \\
\hline & $\begin{array}{l}\text { Неспроможність швів анас- } \\
\text { томозу }\end{array}$ & $5,0 \%(16 / 321)$ \\
\hline & $\begin{array}{l}\text { Перфорація стресових вира- } \\
\text { зок тонкої кишки }\end{array}$ & $3,7 \%(12 / 321)$ \\
\hline & $\begin{array}{l}\text { Кровотеча з судин брижі киш- } \\
\text { ки }\end{array}$ & $2,8 \%(9 / 321)$ \\
\hline & $\begin{array}{l}\text { Гострий тромбоз судин киш- } \\
\text { ківника }\end{array}$ & $2,8 \%(9 / 321)$ \\
\hline & Пневмонія & $1,9 \%(6 / 321)$ \\
\hline & Пролежень з перфорацією & $0,3 \%(1 / 321)$ \\
\hline & $\begin{array}{l}\text { кишки після стентування пух- } \\
\text { лини }\end{array}$ & \\
\hline
\end{tabular}

Таблиця 4. Випадки смерті внаслідок рецидивів КРР

\begin{tabular}{lcc}
\hline \multicolumn{1}{c}{ Ознака } & \multicolumn{2}{c}{ Кількість випадків } \\
\cline { 2 - 3 } & $\mathbf{n}$ & $\%$ \\
\hline Смерть пацієнтів 3 вперше виявленим КРP & 213 & 66,3 \\
Смерть від рецидивів КРР & 61 & 19,0 \\
до 1 року після видалення пухлини & 22 & 36,0 \\
до 2 років після видалення пухлини & 41 & 67,0 \\
після 5 років 3 моменту видалення пухлини & 15 & 24,5 \\
\hline
\end{tabular}


нень 66,3\% (213/321). Смерть внаслідок рецидивування після оперативного видалення пухлини в минулому зафіксовано у 19,0\% (61/321), та у 14,6\% (47/321) діагноз було встановлено до останнього епізоду лікування, хворі отримували паліативну терапію або місцеве оперативне лікування за наявної генералізації пухлини. Кількість випадків появи рецидивів у терміни до 1 року, до 2 років та після 5 років представлені в табл. 4 . Найбільш ранній рецидив спостерігали через 4 міс, найдовший безрецидивний період становив 14 років.

Серед померлих внаслідок рецидиву прогресування пухлинного процесу з метастазуванням у внутрішні органи було відмічено у 54,1\% (33/61) випадків, місцеві ускладнення у вигляді дистанційного розриву кишки та формування абсцесів черевної стінки та кровотечу з пухлини виявляли у 26,2\% (16/61) хворих, оперативне втручання з приводу кишкової непрохідності 3 ускладненнями у ранній післяопераційний період зареєстровано у 19,6\% (12/61) випадків, серед них: гостра серцева недостатність чи тромбоемболія легеневої артерії у хворих на ішемічну хворобу серця, неспроможність швів кишкового анастомозу, неспроможність колостоми, кровотеча із зони оперативного втручання.

\section{ОБГОВОРЕННЯ РЕЗУЛЬТАТІВ ДОСЛІДЖЕННЯ}

Матеріалом дослідження був 321 випадок КРР, проте це лише частина усіх випадків смерті внаслідок цієї онкопатології. Так, відомо, що у Харкові за 5 років (2015-2019рр.) кількість смертей від КРР становила 3828 [1]. Матеріалом, що досліджувався, були випадки КРР у хворих, що померли у стаціонарах, зокрема окремих багатопрофільних лікарень Харкова, водночас смерть у лікувальних закладах є лише частиною всіх випадків. Крім того, відомо, що лише 55\% хворих на КРР отримують спеціалізоване лікування [1]. Отже, цілком закономірною є деяка розбіжність інформації порівняно з даними Національного канцер-реєстру України. Так, серед померлих внаслідок КРР у Харкові за 2015-2019рр. була майже однакова кількість представників різних статей - 49,8\% чоловіків, 50,2\% жінок, тоді як у нашому матеріалі - 48,3 та 51,7\% відповідно.

За нашими даними, пік смертності від КРР припадає на 70-79 років, тоді як за даними літератури частота захворюваності на КРP з віком поступово зростає аж до вікової групи $>85$ років [2]. Це цілком обумовлено загальною високою смертністю у віковому інтервалі $70-79$ років в Україні.

Значно відрізняється від даних Національного канцерреєстру отримана нами інформація щодо кількості пацієнтів 3 КРР, що не прожили 1 року з моменту встановлення діагнозу. У Харкові у 2014-2018 рр. цей показник серед ЗН ободової кишки становив 40,7-45,4\%, раку прямої кишки - 31,3$34,1 \%$. За нашими даними, 79,7\% (256/321) пацієнтів померли у 1 -й рік 3 моменту встановлення діагнозу та не перебували на обліку 66,3\% (213/321) хворих, коли діагноз КРР було встановлено вперше у стаціонарі або під час розтину.

Така розбіжність даних випливає з того, що частина хворих 3 встановленим діагнозом КРР, які перебувають на обліку, помирають не у лікувальних закладах, тоді як у стаціонар потрапляють пацієнти з невстановленим раніше діагнозом, ознаками кишкової непрохідності чи перитоніту, які потребують ургентної спеціалізованої, часто хірургічної медичної допомоги. При цьому, за нашими даними, частка смертей від прогресування пухлинного процесу у вигляді метастазів у внутрішні органи становила лише $27,1 \%$ від загальної кількості випадків смертей внаслідок КРР.

Розглядаючи структуру смертності пацієнтів, слід зазначити, що саме місцеві ускладнення КРР та ускладнення після операцій, що виконувалися з приводу місцевих ускладнень пухлинного процесу є основною причиною смерті хворих у стаціонарі - 71,0\% випадків. Відповідно, IV стадію (стадію D за Duckes) захворювання було виявлено лише у $43,6 \%$ хворих, при цьому серед цих випадків локалізація метастазів лише в 1 органі відмічена у 51,4\% хворих. За даними окремих авто- рів, метастазування КРР у 1 орган спостерігається у 20-62\% випадків, переважно у печінку та легеню [3, 4]. Метастази у кістки, селезінку, головний мозок, серце при КРР відмічають рідко та вкрай рідко вони бувають ізольованими, без наявних метастазів у інші органи [4]. За нашими даними, всі випадки метастазів у вказані органи супроводжувалися наявністю метастазів у печінку чи легеню.

Серед ускладнень після операцій найчастіше виникали гостра серцева недостатність чи тромбоемболія легеневої артерії у хворих із супутньою патологією - ішемічною хворобою серця - у 42,0\% (50/119), а також некроз чи неспроможність колостоми та кишкового анастомозу - у 26,0\% (32/119) пацієнтів.

Слід вважати, що наведені дані свідчать про високий показник занедбаності КРР, що призводить до смерті, перш за все, саме від місцевих ускладнень, а не внаслідок генералізації пухлинного процесу з інвазією у суміжні органи чи метастазуванням. Необхідними є впровадження заходів щодо ранньої діагностики КРР, а також розробка нових методів своєчасної діагностики та лікування як самого КРР, так і його ускладнень.

\section{ВИСНОВКИ}

1. Серед померлих у стаціонарі багатопрофільних лікарень КРР є причиною смерті у 4,83\%.

2. Серед померлих внаслідок КРР локалізацією, що найчастіше відмічалася, була сигмоподібна кишка та ректосигмоїдна зона - у 37,5\% хворих. Зона сліпої кишки, ілеоцекального кута та апендиксу - у 16,5\%, прямої кишки - 11,9\%.

3. Серед пацієнтів, що померли у стаціонарі від KPP, IV стадію захворювання виявляли лише у 43,6\% (140/321) випадків, серед них найбільш поширеною локалізацією метастазів були печінка, легеня та очеревина - у 39,5; 21,8 та 11,2\% відповідно. У $51,4 \%$ пацієнтів метастази були в 1 органі. У $36,76 \%$ віддалені метастази та проростання у внутрішні органи були відсутні.

4. Серед причин смерті хворих на КРР найбільш поширеними є місцеві ускладнення - генералізація пухлинного процесу та перфорація пухлини - у 27,1 та 18,3\% хворих відповідно.

5. Серед хворих, що померли у стаціонарі внаслідок КРР, лікування у стаціонарі з приводу ЗН та їх ускладнень вперше відмічали у 66,3\% хворих. Смерть від рецидивів у пацієнтів, яким пухлину було видалено раніше, наступила у $19,0 \%$, серед них смерть внаслідок рецидиву у перший рік після видалення пухлини зафіксована у $36,5 \%$, у перші 2 роки - у $67,0 \%$. Смерть від рецидивування через 5 років після видалення первинної пухлини встановлено у $24,5 \%$ хворих.

\section{СПИСОК ВИКОРИСТАНОЇ ЛІТЕРАТУРИ}

1. Федоренко, З.П. Гулак, Л. О., Михайлович, Ю Й., Горох, $€$ Л. Рижов, А. Ю. Сумкіна, О. В., \& Куценко, Л. Б. (2020). Рак в Україні, 2018-2019. Захворюваність, смертність, показники діяльності онкологічної служби. Гол. ред. О. О. Колеснік. Бюлетень Національного канцер-реєстру України, 21, 101.

2. Lukejohn, W. \& Velayos, F. (2015). Colorectal Cancer Screening and Surveillance in the Elderly: Updates and Controversies. Gut and Liver, 9(2), 143-151. doi: $10.5009 /$ gnl14302.

3. Sadahiro, S., Suzuki, T., Tanaka, A., Okada, K., \& Kamata, H., (2013). Hematogenous Metastatic Patterns of Curatively Resected Colon Cancer Were Different from Those of Stage IV and Autopsy Cases. Japanese Journal of Clinical Oncology, 43(4), 444-447. doi: 10.1093/jjco/hyt002.

4. Suresh Babu, M. C., Garg, S., Lakshmaiah, K. C., Babu, K. G., Kumar, R. V., Loknatha, D.,... Rudresha, A. H. (2017). Colorectal cancer presenting as bone metastasis. Journal of Cancer Research and Therapeutics, 13, 80-3. doi: $10.4103 / 0973-1482.181177$.

\section{Анализ смертности больных колоректальным} раком в многопрофильных больницах Харькова

И.И. Яковцова, И.В. Ивахно, А.С. Якименко, О.В. Долгая,

С.В. Данилюк, Т.М. Чертенко

Харьковская медицинская академия последипломного образования

Резюме. Колоректальный рак (КРР) является злокачественной опухолью, которая может вызывать смертельные осложнения даже без значительного прогрессирования опухолевого процесса, однако КРР может характеризоваться быстрой генерализацией без местных осложнений. Цель исследования определить основные клинико-морфологические особенности 
КРР по данным аутопсии. Материалы и методы. Проведен анализ 321 аутопсии больных, умерших вследствие КРР в стационарах г. Харьков. На основании протоколов вскрытия и историй болезни было исследованы следующие данные: пол, возраст пациентов, локализация опухоли, ее гистологическое строение, характер распространения, данные анамнеза, непосредственная причина смерти. Результаты. Среди 6635 умерших в стационарах многопрофильных больниц КРР был причиной смерти у 4,83\% (321 случай). Первичная опухоль локализовалась у $37,5 \%$ больных в сигмовидной кишке и ректосигмоидной зоне, у 16,5\% - в слепой кишке, у 11,9\% - в прямой кишке. Среди умерших IV стадию заболевания отмечали только в $43,6 \%$ (140 из 321) случаев, среди них наиболее распространенной локализацией метастазов были печень, легкое и брюшина 39,$5 ; 21,8$ и $11,2 \%$ соответственно; у 51,4\% пациентов метастазы выявляли в одном органе. Среди причин смерти больных КРР наиболее распространенными были местные осложнения генерализация опухолевого процесса и перфорация опухоли были причинами смерти в 27,1 и $18,3 \%$ случаев соответственно. Смерть после операций, проводившихся по поводу местных осложнений, чаще всего наступала в результате сердечной недостаточности или тромбоэмболии легочной артерии. Среди умерших лечение в стационаре по поводу рака и его осложнений впервые отмечали у 66,3\%. Смерть в результате рецидивов в 1-, 2-й годы и после 5 лет с момента удаления опухоли наступила у 36,$5 ; 67,0$ и 24,5\% соответственно. Выводы. Среди умерших в стационаре многопрофильных больниц КРР был причиной смерти у 4,83\%. Локализация КРР, которую отмечали чаще всего, - сигмовидная кишка и ректосигмоидная зона $37,5 \%$ случаев. Среди причин смерти больных КРР наиболее распространенными были местные осложнения. Генерализация опухолевого процесса была причиной смерти только в 18,3\% больных. У 66,3\% пациентов смерть вследствие КРР наступала без предварительного лечения. Смерть от рецидивов у больных, у которых опухоль была удалена ранее, отмечалась в 19,0\% случаев, среди них в первые 2 года - у 67,0\%

Ключевые слова: колоректальный рак; аутопсия; клиникоморфологический анализ.

\section{Analysis of mortality of patients with colorectal cancer in Kharkiv`s multidisciplinary hospitals \\ I.I. Yakovtsova, A.S. Yakimenko, I.V. Ivakhno, S.V. Danyliuk, O.V. Dolgaya, T.M. Chertenko}

Kharkiv Medical Academy of Postgraduate Education

Abstract. Colorectal cancer (CRC) is a malignance which can lead to mortal complications even without significant tumor progression. CRC can be also characterized by rapid spreading. The aim of current investigation is to define the main clinical and pathological features of CRC by autopsy. Material and Methods. The results of 321 autopsies of patients who died from CRC in Kharkov hospitals were analyzed. According to autopsy reports and medical records there were investigated such data as: sex, age of patients, tumor localization, their histolopathology, spreading level, anamnesis data, direct case of death. Results. Of those who died in multiprofile hospitals ( 6635 cases), CRC was a main cause of death in $4.83 \%$ (321 cases). Localization of the primary tumor in sigmoid colon and rectosigmoidal region was in $37.5 \%$, in cecum - in $16.5 \%$, in rectum - in $11.9 \%$. IV tumor stage was only in $43.6 \%(140 / 321)$ of cases, among them more common localizations of metastases were: liver, lungs and peritoneum in $39.5 \%, 21.8 \%$ and $11.2 \%$ respectively. Metastases only in one organ were in $51.4 \%$. Among patients who died from CRC, deaths were caused more commonly by local complications; tumor generalization and perforation of tumor were the causes of death in $27.1 \%$ and $18.3 \%$ respectively. Death after surgery for local complications was most often due to heart failure or pulmonary embolism. Among patients who died from CRC $66.3 \%$ were received a treatment of cancer or complications for the first time. Deaths from recurrences within first, second years and after five-year postoperative period were in $36.5 \%, 67.0 \%$ and $24.5 \%$ respectively. Conclusions. Of those who died in multiprofile hospitals, CRC was a main cause of death in $4.83 \%$. The most common localization of CRC was sigma or rectosigmoidal region - in $37.5 \%$. The most common causes of death among patients who died from CRC were local complications. Tumor spreading was the case of death in $18.3 \%$. The $66.3 \%$ of patients, who died from CRC, did not get any cancer treatment previously. Recurrences which caused fatal outcome among patients after surgery in the past were in $19.0 \%$, among them within first 2 years - in $67.0 \%$.

Key words: colorectal cancer; autopsies; clinical-pathological investigation.

Aдреса для листування:
Iвахно Ігор Володимирович
61045, Харьков, просп. Московский, 195
E-mail: IgorV.Ivakhno@gтаil.com
0956653991
Correspondence:
Ivakhno Igor
195 Moskovsky ave., Kharkiv 61045
E-mail: IgorV.Ivakhno@gmail.com
0956653991

